\title{
Suicide Rate in a Mediterranean Island: North Cyprus
}

\section{Ipek Sonmez ${ }^{1 *}$, Ali Bozkurt ${ }^{1}$ and Abidin Akbirgun ${ }^{2}$}

${ }^{1}$ Near East School of Medicine Department of Psychiatry, Nicosia, TRNC, Turkey

${ }^{2}$ Baris Mental Hospital, Nicosia, TRNC, Turkey

\begin{abstract}
Objective: This study determines the distribution of suicides according to years and seasons as well as the frequency of completed suicides in Turkish Republic of Northern Cyprus.

Method: All suicides that resulted in death in the Turkish Republic of Northern Cyprus (TRNC) between the years of 2010-2013 were included in the study.

Results: Fifty-six individuals committed suicide between 2010 and 2013. Male/female ratio was estimated to be 2.5. The mean rate of suicides per 100000 individuals for all 4 years was, 4.89 . In males, the rate of violent suicide attempts was $82.5 \%$ (n: 33/40), while this rate was $56.2 \%(n: 9 / 16)$ in females.

Conclusions: The data from the current study suggest that the rate of suicide in North Cyprus Turkish Republic is higher than the rate in most Muslim countries, which is lower than the general world average and close to the rates observed in Turkey and South Cyprus. The male/female ratio was closer to that found in Turkey, Iran and Japan. Finally, the method and seasonal characteristics were similar to previous reports in the literature.
\end{abstract}

\section{Keywords: Suicide; Cyprus; Gender; Age; Season}

\section{Introduction}

Suicide is a complex human behavior that has biological, psychological and sociological origins. It may appear as suicidal ideation, suicide attempt and suicide commitment. Suicide seen in a wide spectrum, ranging from normal individuals reacting to life conditions that cause strain to patients with severe mental disorders [1].

World Health Organization (WHO) divides suicide into two categories: suicide attempts and completed suicides. Suicide attempts are voluntary attempts to kill or harm oneself that do not result in death [2]. For each suicide attempt that results in death, at least 30 suicide attempts are encountered [3]. Kessler et al., lifetime pre]valence rates of suicidal ideation, suicidal plans and suicide attempts are $13.5 \%, 3.9 \%$ and $4.6 \%$, respectively [4]. The number of suicides in the world totaled 782,000 in 2008, according to the WHO estimate. Suicide accounted for $1.4 \%$ of total mortality and $15 \%$ of injury mortality [5]. While suicide attempts are more frequent in women, completed suicides are more frequent in men [6]. Of all suicides, $84 \%$ are seen in countries with low to intermediate income level; $49 \%$ of all suicides occur in China or India [7].

Suicide rates differ among populations ranging from 5 in 100000 and less to 25 in 100000 and more. While the rate of completed suicides per 100000 individuals is approximately 30 in countries such as Finland, Latvia and Russia [8] 25 in Japan [9]; 18.1 in Serbia [10]; and 9.7 in Australia [11], this ratio decreases below 6.5 in Latin American countries [8]. The rate of suicide is lower in countries with stronger religious beliefs. For example, in Thailand, where Buddhism is widespread, the rate is 5.7 in 100000, and in the Philippines, where Catholicism is common, the rate is 5 in 100000 [12].

While the rate of suicide in men is 3-4 times greater than women in Western Countries, in Asian countries, the suicide rates for men and women are more equal [13]. The ratio of suicide in men to suicide in women is highest in Puerto Rico (6.6), Slovakia (6.6) and Poland (6.4) and lowest in China (0.9), which is currently the only country where the rate is higher for females than for males [5].

Suicide methods are divided into two categories, those involving violent methods (hanging, drowning, getting injured from firearms and jumping from height) and those involving nonviolent methods (drug poisoning) [14]. The most commonly used suicide methods are taking an overdose of drugs, poisoning, hanging and shooting oneself with firearms [9]. While men typically choose hanging or jumping from a height, women prefer drug overdose, poison or cutting the ankles [11].

Many risk factors for suicide have been defined. These risk factors are: age, gender, living in a rural/urban area, race, month of birth socioeconomic factors, marital status, interpersonal relationships and life events, medical and psychiatric disorders, history of suicide attempt, and environmental conditions, such as sunlight and temperature [15-23].

Two studies have been conducted regarding suicide in Cyprus. Yağlı et al. [24], investigated suicides between 1970 and 1990 in Northern Cyprus, and Zacharakis et al. [25], investigated suicide in Southern Cyprus between 1988 and 1999. As the study conducted in Northern Cyprus includes data from over 24 years ago and no study about the topic has been conducted since this time, it would be beneficial to evaluate completed suicides in Northern Cyprus in recent times to compare data with the more recent study performed in Southern Cyprus.

The hypothesis of the study was that in a country which has a mostly Muslim population and where the summer period is very long the suicide rates can be higher than other Muslim countries and can have a seasonality.

The aim of the present study is to investigate the suicide rate, the

*Corresponding author: Ipek Sonmez, Assistant Professor of Psychiatry, Near East School of Medicine Department of Psychiatry, Nicosia, TRNC, Turkey, Tel: 90-392-6751000; E-mail: dr_ipeks@yahoo.com

Received January 13, 2015; Accepted March 18, 2015; Published March 25, 2015

Citation: Sonmez I, Bozkurt A, Akbirgun A (2015) Suicide Rate in a Mediterranean Island: North Cyprus. J Psychiatry 18: 273 doi: 10.4172/2378-5756.1000273

Copyright: (c) 2015 Sonmez I, et al. This is an open-access article distributed under the terms of the Creative Commons Attribution License, which permits unrestricted use, distribution, and reproduction in any medium, provided the original author and source are credited 
distribution of suicides according to years and seasons, and to evaluate these factors in comparison to the literature.

\section{Method}

This is a retrospective, descriptive study based on all available suicide records kept by the General Police Directorate of the Turkish Republic of Northern Cyprus. Since electronic records were initiated in 2010, the study covers the period of 2010-2013 where the data is reliable. All suicides that resulted in death in the Turkish Republic of Northern Cyprus (TRNC) between the years of 2010-2013 were included in the study. Data related to the registry of birth were obtained from the Civil Registry Office.

The approval of the ethical committee of the Near East University School of Medicine was taken before conducting the study. Ethics Committee conforms to the provisions of the Declaration of Helsinki (as revised in Edinburg 2000).

Descriptive statistics were calculated. All data are presented as frequencies, percentages, means and standard deviations. All descriptive statistics are provided throughout the text and summarized in tables. Statistical calculations were conducted using Microsoft Excel software.

\section{Results}

Fifty-six individuals committed suicide between 2010 and 2013. Forty of these individuals were males $(71.4 \%)$ and 16 were females $(28.6 \%)$, and the male/female ratio was 2.5 . The mean age of all cases was $41.70 \pm 17.12$; the mean age was $42.75 \pm 14.83$ in males and $39.06 \pm$ 22.20 in females. The age range of cases was $14-86,19-75$ in males and $14-86$ in females.

The number of individuals who committed suicide is provided with respect to years in Table 1 . The number of suicides between the years $2010-2013$ was $17,14,17$ and 8 , respectively. The last official census conducted in TRNC was in 2011 and it was used in this study for determination of suicide rates. The rate of suicides per 100000 individuals was 5.94 in 2010, 4.89 in 2011, 5.94 in 2012 and 2.79 in 2013 , and the mean of all 4 years was 4.89 .

The methods of suicide were summarized in Table 2.

In males, the rate of violent suicide attempts was $82.5 \%$ (n: $33 / 40$ ), while this rate was $56.2 \%$ (n: 9/16) in females. The most commonly used methods was hanging in males $(16 ; 40 \%)$, and taking drugs for females $(7 ; 43.8 \%)$.

The distribution of suicides according to seasons is provided in Table 3.

The season when the rate of suicide was highest was summer, and the season when it was lowest was spring.

\section{Discussion}

The rates of suicide in our study were higher when we compared our data with that of the previous studies conducted in Southern Cyprus and TRNC [24]. According to World Health Organization data of 2008, the frequency of suicide in Cyprus was 4.5 per 100000 individuals. These data of the World Health Organization are thought to belonging to Southern Cyprus. It is generally reported in the literature that suicide rates are lower in Muslim countries [25,26]. Our findings note similar suicide rates when compared with 2008 data from the Christian population in Cyprus, although it was mildly higher (4.5/4.89). Cyprus Island hosted different cultures for centuries and was a British Colony for 80 years (1878-1959). In Cyprus, which has been divided into North and South Cyprus, constituting Turkish and Greek regions since 1974, the borders were opened in 2003 for the first time. Although the Muslim and Christian communities live on the same island, they have been ruled differently and they have had different economies. Thus, many factors other than religion may have an impact on rates of suicide in North and South Cyprus.

In Latin American and Muslim Middle Eastern countries, the rates of suicide have been found to be less than 6.5 per 100000 [8]. In countries such as Finland, Latvia, Russia, Sri Lanka and South Korea, the suicide rates have been reported to be over 30 in $100000[5,8]$. In the United States of America, the suicide rate is reported to be 14 in 100000 [27]. The suicide rates that we found in this study are slightly higher than those found in some countries, but the rates are similar to data obtained from studies conducted in Turkey and South Cyprus. In the study conducted in Turkey, suicide rates were reported to be 3.96 in 2007 and 4.26 in 2012 [28]. The global rate of suicide reported by the World Health Organization is 11.6 in 100000 and our rates are lower also than this $[29,30]$.

According to World Health Organization data on completed suicides, the male-to-female ratio is 4 in the European region, 3.6 in the American region, 1.1 in the East Mediterranean region, and 1.3 in the Western Pacific region [5].

The male-to-female ratios reported in some other countries are: 6

\begin{tabular}{|c|c|c|}
\hline YEAR & (n) & $\%$ \\
\hline 2010 & 17 & 30.4 \\
\hline 2011 & 14 & 25 \\
\hline 2012 & 17 & 30.4 \\
\hline 2013 & 8 & 14.3 \\
\hline Total & 56 & 100 \\
\hline
\end{tabular}

Table 1: The Number of Individuals who Committed Suicide with Respect to Years.

\begin{tabular}{|l|c|c|c|}
\hline \multicolumn{1}{|c|}{ METHOD } & $\begin{array}{c}\text { MALE } \\
\mathbf{n}(\mathbf{\%})\end{array}$ & $\begin{array}{c}\text { FEMALE } \\
\mathbf{n}(\%)\end{array}$ & $\begin{array}{c}\text { TOPLAM } \\
\mathbf{n}(\mathbf{\%})\end{array}$ \\
\hline Hanging & $16(40.0)$ & $4(25.0)$ & $20(35.7)$ \\
\hline Taking Drugs & $7(17.5)$ & $7(43.8)$ & $14(25.0)$ \\
\hline Firearms & $12(30.0)$ & $0(0.0)$ & $12(21.4)$ \\
\hline Jumping From A Height & $2(5.0)$ & $2(12.5)$ & $4(7.1)$ \\
\hline Self-Stabbing & $2(5.0)$ & $0(0.0)$ & $2(3.6)$ \\
\hline Drowning In The Sea & $0(0.0)$ & $2(12.5)$ & $2(3.6)$ \\
\hline Crashing Into The Wall With A Motor Vehicle & $1(2.5)$ & $0(0.0)$ & $1(1.8)$ \\
\hline Burning Oneself & $0(0.0)$ & $1(6.3)$ & $1(1.8)$ \\
\hline
\end{tabular}

Table 2: Suicide Methods.

\begin{tabular}{|c|c|c|c|c|c|}
\hline MONTHS & NUMBER & PERCENTAGE & SEASON & NUMBER & PERCENTAGE \\
\hline December & 4 & 7.1 & \multirow{3}{*}{ Winter } & \multirow{3}{*}{18} & \multirow{3}{*}{32} \\
\hline January & 6 & 10.7 & & & \\
\hline February & 8 & 14.3 & & & \\
\hline March & 4 & 7.1 & \multirow{3}{*}{ Spring } & \multirow{3}{*}{17} & \multirow{3}{*}{30} \\
\hline April & 6 & 10.T7 & & & \\
\hline May & 7 & 12.5 & & & \\
\hline June & 9 & 16.1 & \multirow{3}{*}{ Summer } & \multirow{3}{*}{16} & \multirow{3}{*}{29} \\
\hline July & 3 & 9.4 & & & \\
\hline August & 4 & 7.1 & & & \\
\hline September & 2 & 3.6 & \multirow{3}{*}{ Autumn } & \multirow{3}{*}{5} & \multirow{3}{*}{9} \\
\hline October & 1 & 1.8 & & & \\
\hline November & 2 & 3.6 & & & \\
\hline
\end{tabular}

Table 3: The Distribution of Suicides by Months and Seasons. 
in Greece [5]; 4.7 in Israel [5]; 4.4 in South Cyprus [5]; 2.3 in Turkey [31]; 2.4 in Iran [29] 2.7 in Japan [9]; and 1.8 in Pakistan. It is worth noting that the male-to-female ratios are lower in Asian countries.

In North Cyprus, suicide rates per 100000 individuals were 6.65 in men and 2.95 in women. The male-to-female ratio was 2.5 when taken numerically. The corrected ratio, taking the number of women and men in the population into account, was 2.25 . When these rates are compared with the literature, they are similar to data from Turkey, Iran and Japan.

Suicide methods were further classified as involving violent (hanging, drowning, shooting and jumping) or nonviolent (poisoning) methods [14].

Males are more likely than females to die by all forms of violent death, including suicide [30].

While the most commonly used method of suicide in United States of America is the use of firearms [31], in countries such as China and Korea, where there are large rural populations, pesticides are reported as the most widespread method [32]. In Australia, Japan, New Zealand, Pakistan, Thailand and India, the most common method is hanging, and in Hong Kong and Singapore, jumping from a height was reported to be the most frequent method $[32,33]$.

In a study that investigated the relationship between suicide methods and gender, age and education in Iran, the most common method was hanging in men and burning oneself in women. Hanging and burning oneself was more common in individuals with lower education levels, and drug poisoning was more common in individuals with higher education levels [34]. In South Cyprus, the most common suicide methods in women were jumping from a height, drug poisoning and hanging [25]. In our study, women preferred drug poisoning, which is the most common nonviolent method. In Turkey, Brazil, Argentina, Thailand, Austria and Germany, the most widespread suicide method is hanging $[28,35]$. As in our country, in many countries such as Turkey, Canada, America, Austria, Hungary, Denmark, Holland and Norway, women mostly prefer the method of using chemicals $[28,35]$.

The literature suggests that the rate of completed suicides increases with age. One fourth of all suicides in the USA and one third of all suicides in Holland have been reported to be performed by individuals 60 years of age or older [1]. The World Health Organization report in 2000 has shown that in the East Mediterranean region, the rate of suicides peaked between ages 15 to 29 in women and over 60 for men [36]. However, in our study, the mean age was found to be 39-42 in both women and men, which is different from the literature. Similar data were found in a study conducted in Ireland investigating suicide data of 22 years where the highest suicide rates were found among individuals between 40 and 44 years of age [37].

In accordance with studies conducted in many different countries up to the present, in our study, the seasons in which suicide attempts were observed most often were summer and spring. July and March were the months where suicides were seen most often, and October, November and December were the months were suicides were seen least. In a study conducted in Austria, the highest suicide rates were seen between March and May, while the lowest rates were seen in November. Sunlight was specifically related to violent suicides. The argument that sunlight increases impulsivity by acting on serotonin transmission and thus increases suicidal acts has been suggested [38]. In a study that investigated suicide attempts and completed suicides across 20 years in Italy, suicide attempts were prominently related to sunlight exposure and inversely related to the amount of rainfall [20].

Our study has some limitations. The first limitation of the study is that the study was a retrospective study which was restricted with 4 years since the police files were acceptable only for that period. Another limitation was that the files were including information only about age, gender, date of suicide and suicide method.

\section{Conclusion}

The data from the current study suggest that the rate of suicide in North Cyprus Turkish Republic is higher than the rate in most Muslim countries, which is lower than the general world average and close to the rates observed in Turkey and South Cyprus. The male/female ratio was closer to that found in Turkey, Iran and Japan. Finally, the method and seasonal characteristics were similar to previous reports in the literature.

\section{References}

1. Özgüven HD (2008) İntihar Davranışının Epidemiyolojisi. Türkiye Klinikleri J Psychiatry-Special Topics 3: 1-7.

2. World Health Organization: The Global Burden of Disease: 2004 update Geneva: WHO Press; 2008.

3. Sayıl I (1992) İntiharı konu alan yayınlar üstüne bir çalışma. Kriz Dergisi 1 $38-41$.

4. Kessler RC, Borges R, Walters E (1999) Prevalence of and risk factors for lifetime suicide attempts in the National Comorbidity Survey. Arch Gen Psychiatry 56: 617-626.

5. Värnik P (2012) Suicide in the World. Int J Environ Res Public Health 9: 760 771.

6. Fawcett J, Shaughnessy R (1989) The suicidal patient. JA Flaherty, RA Channon, JM Davis (Eds.), Psychiatry Chicago.

7. Phillips MR, Cheng HG (2012) The changing global face of suicide. Lance 379: 2318-2319.

8. Mann JJ, Apter A, Bertolote J, Beautrais A, Currier D, et al. (2005) Suicide prevention strategies: a systematic review. JAMA 294: 2064-2074.

9. Sayıl I, Devrimci ÖH (2002) Suicide and suicide attempts in Ankara in 1998 result of the WHO/EURO. Multicentre Study of Suicidal Behaviour Crisis 23 11-16.

10. Dedic G (2014) Gender differences in suicide in Serbia within the period 20062010. Vojnosanit Pregl 71: 265-270.

11. Moscicki EK (1997) Identification of suicide risk factors using epidemiologic studies. Psychiatr Clin North Am 20: 499-517.

12. Hendin H, Vijayuakumar L, Bertolete JM (2008) Epidemiology of suicide in Asia. In: Hendin H, Phillips MR, Vijayakumar L, et al., eds. Suicide and Suicide Prevention in Asia. Geneva, Switzerland: World Health Organization: 7-18.

13. Möller-Leimkühler AM (2003) The gender gap in suicide and premature death or: why are men so vulnerable? Eur Arch Psychiatry Clin Neurosci 253: 1-8.

14. Ajdacic-Gross V, Bopp M, Ring M, Gutzwiller F, Rossler W (2010) Seasonality in suicide- a review and search of new concepts for explaining the heterogeneous phenomena. Soc Sci Med 71: 657-666.

15. Qin P (2005) Suicide risk in relation to level of urbanicity. A population-based linkage study. Int J Epidemiol 34: 846-852.

16. Kung HC, Pearson JL, Liu X (2003) Risk factors for male and female suicide decedents ages 15-64 in the United States. Soc Psych Psych Epidemiol 38 : 419-426.

17. Rock D, Greenberg D, Hallmayer J (2006) Season of birth as a risk factor for the seasonality of suicidal behaviour. Eur Arch Psychiatry Clin Neurosci 256: 98-105.

18. Lorant VA (2005) European comparative study of marital status and socioeconomic inequalities in suicide. Soc Sci Med 60: 2431-2441. 
19. Smith JC, Mercy JA, Conn JM (1988) Marital status and the risk of suicide. Am J Public Health 78: 78-80.

20. Preti A (1997) The influence of seasonal change on suicidal behaviour in Italy. J Affect Disord 44: 123-130

21. Qin $P$, Agerbo E, Mortensen PB (2003) Suicide risk in relation to socioeconomic, demographic, psychiatric, and familial factors: A National register-based study of all suicides in Denmark, 1981-1997. Am J Psychiatry 160: 765-772.

22. Töro K (2009) Relationship between suicidal cases and meteorological conditions. J Forensic Leg Med 16: 277-279.

23. Kim Y, Kim H, Kim DS (2011) Association between daily enviromental temperature and suicide mortality in Korea (2001-2005). Psychiatry Res 186: 390-396.

24. Yağıı M, Kırı S, Eskici MA (1992) Kuzey Kıbrıs Türk Cumhuriyetinde İntihar. Kriz Dergisi 1: 32-37.

25. Zacharakis CA, Hadjivassilis $V$, Madianos MG, Papadimitriou GN, Stefanis CN (2005) Suicide in Cyprus 1988-1999. Eur Psychiatry 20: 110-114.

26. Eskin M (2004) The effects of religious versus secular education on suicide ideation and suicidal attitudes in adolescents in Turkey. Soc Psychiatry Psychiatr Epidemiol 39: 536-542.

27. Kessler RC, Berglund P, Borges G, Mock M, Wang PS (2005) Trends in suicide ideation, plans, gestures, and attempts in the United States, 1990-1992 to 2001-2003. JAMA 293: 2487-2495.

28. Enginyurt Ö, Özer E, Gümüş B, Demir EY, Çankaya S (2014) Evaluation of suicide cases in Turkey, 2007-2012. Med Sci Monit 20: 614-623.

29. Shirazi HR, Hosseini M, Zoladl M, Molekzadeh M, Momeninejad M, et al.
(2012) Suicide in the Islamic Republic of Iran: an integrated analysis from 1981 to 2007. East Mediterr Health J 18: 607-613.

30. Bozzay ML, Liu RT, Kleiman EM (2014) Gender and age differences in suicide mortality in the context of violent death: Findings from a multi-state populationbased surveillance system. Compr Psychiatry 55: 1077-1084.

31. Brent DA, Bridge J (2003) Fire arms availability and suicide: evidence, interventions, and future directions. Am Behav Sci 46: 1192-1210.

32. Ung EK (2003) Youth suicide and parasuicide in Singapore. Annals of the Academy of Medicine 32: 12-18.

33. Yip PS (1996) Suicides in Hong Kong, Taiwan and Beijing. Br J Psychiatry 169: 495-500.

34. Shojaei A, Moradi S, Alaeddini F, Moradi S, Alaeddini F, et al. (2014) Association between suicide method, and gender, age, and education level in Iran over 2006-2010. Asia Pac Psychiatry 6: 18-22.

35. Ajdacic-Gross V, Weiss MG, Ring M, Hepp U, Bopp M, et al. (2008) Methods of suicide patterns derived from the WHO mortality database. Bull World Health Organ 86: 726-732.

36. Rezaeian M (2007) Age and sex suicide rates in the Eastern Mediterranean Region based on global burden of disease estimates for 2000. East Mediterr Health J 13: 953-960.

37. Casey P, Gemmell I, Hiroeh U, Fulwood C (2012) Seasonal and sociodemographic predictors of suicide in İreland: a 22 year study. J Affect Disord 136: 862-867.

38. Vyssoki B, Praschak-Rieder N, Sonneck G, Blüml V, Willeit M, et al. (2012) Effects of sunshine on suicide rates. Compr Psychiatry 53: 535-539. 